\title{
Türkiye'nin Sucul Ortamlarında Ăgır Metal Üzerine Yapılan Araştırmaların Tarihsel İncelemesi ve Bibliyometrik Analizi (2000-2020)
}

\author{
Ayşenur BASMACI Zeynep BOSTAN V. Zülal SÖNMEZ* Nüket SİVRI \\ İstanbul Üniversitesi-Cerrahpaşa, Mühendislik Fakültesi, Çevre Mühendisliği Bölümü, Avcllar, İstanbul, Türkiye
}

Atıf yapmak için: Basmacı, A., Bostan, Z., Sönmez, V.Z. \& Sivri, N. (2021). Türkiye'nin Sucul Ortamlarında Ağır Metal Üzerine Yapılan Araştırmaların Tarihsel İncelemesi ve Bibliyometrik Analizi (2000-2020). Anadolu Çev. ve Hay. Dergisi, 6(4), 567-577.

How to cite: Basmacı, A., Bostan, Z., Sönmez, V.Z. \& Sivri, N. (2021). A Historical Review and Bibliometric Analysis of Research on Heavy Metal in Aquatic Environments of Turkey (2000-2020). J. Anatolian Env. and Anim. Sciences, 6(4), 567-577.

: https://orcid.org/0000-0003-0911-4146 D: https://orcid.org/0000-0002-3310-053X (D): https://orcid.org/0000-0002-7488-2996 iD: https://orcid.org/0000-0002-4269-5950
Öz: Su kalitesinin korunması ve kirliliğin önlenmesi amacıyla, fizikokimyasal ve biyolojik parametrelerin izlenmesi ve denetlenmesi gerekmektedir. Bu hedef doğrultusunda yürütülen bilimsel çalışmalar, yapılacak diğer çalışmalar için de temel teşkil etmektedir. Bu çalışmada amaç, Türkiye'de tatlı su (göl, nehir, akarsular, haliç gibi) ve deniz suyu karakteri taşıyan yüzey sularında, 2000-2020 yılları arasında yayınlanan "ağır metal" ile ilgili araştırmaların bibliyometrik analizinin yorumlanmasıdır. Su kalitesinde fizikokimyasal ve biyolojik değişmelere neden olan "ağır metal”ler ile ilgili uluslararası araştırma eğilimleri dikkate alınarak, "deniz suyu" ve "tatlı su" anahtar kelimeler olarak seçilmiştir. Sadece yıl sınırı konulan bu çalışmada, küresel araştırma eğilimleri dikkate alındığında, uluslararası bilimsel dergilerde yayımlanan toplamda 1661 bilimsel çalışma tespit edilmiştir. Bu çalışmalardan "Türkiye" sucul alanlarında yapılmış, 112 orjinal çalışma incelenmiștir. Anahtar kelime olarak "deniz suyu", "ağır metal" ve "Türkiye" için 58 adet; "tatlı su", "ağır metal" ve "Türkiye" kullanıldığında ise, 56 adet makale sonuçları alınmıștır. Sonuç olarak, sucul alanlarda yapılan su kalitesi içerikli çalışmalarda, yerinde örnekleme ve analiz yöntemlerine dayalı ağır metal izleme araştırmalarının önemi ve takip çalışmalarına yer verilmesi gerekliliği belirlenmiştir.

Anahtar kelimeler: Bibliyometrik analiz, ağır metal, deniz suyu, tatlı su, Türkiye.

\section{A Historical Review and Bibliometric Analysis of Research on Heavy Metal in Aquatic Environments of Turkey (2000-2020)}

*Corresponding author's:

V. Zülal SÖNMEZ

Istanbul University-Cerrahpașa

Engineering Faculty, Environmental

Engineering Department

Avc1lar, Istanbul, Turkey

凶: zulal.sonmez@iuc.edu.tr

\begin{abstract}
In order to protect water quality and prevent pollution, it is necessary to monitor and control physicochemical and biological parameters. Scientific studies carried out in line with this goal constitute the basis for other studies to be carried out. This study aims to interpret the bibliometric analysis of the studies carried out on "heavy metal" published between 2000-2020 in freshwater (such as lakes, rivers, streams, estuaries) and surface waters with seawater characteristics in Turkey. Taking into account the international research trends on "heavy metals" that result in physicochemical and biological changes in water quality, "seawater" and "freshwater" were chosen as keywords. Considering the global research trends, a total of 1661 scientific studies published in international scientific journals were identified in this study with a year limit. Among these studies, 112 original studies, which were carried in the aquatic areas of "Turkey," were examined. When "seawater," "heavy metal," and "Turkey" were used as keywords, 58 articles results were found. When the "freshwater," "heavy metal," and "Turkey" were used as keywords, 56 article results were obtained. As a result, it was determined that heavy metal monitoring research based on on-site sampling is important, and analysis methods and follow-up studies are necessary for studies carried out on water quality.
\end{abstract}

Keywords: Bibliometric analysis, heavy metal, seawater, freshwater, Turkey. 


\section{GíRiş}

Sucul ekosistemlerin kirlenmesi, çevre kirliliğinin en temel konu başlıklarından birisidir. $\mathrm{Bu}$ kirliliğin alt başlıklarından olan ağır metal kirliliği sebebiyle, gerek doğal gerekse de yapay sucul ortamlarda canlıların hayatları tehlikeye girmektedir (Karadavut vd., 2012a). Ağır metalin spesifik bir tanımı olmamasına rağmen literatürde, yüksek atom ağırlığına ve sudan beş kat daha fazla olan yüksek yoğunluğa sahip doğal olarak oluşan bir element olarak tanımlanmıştır (Banfalvi, 2011). Özgül ağırlığ $3 \mathrm{mg} / \mathrm{cm}^{3}$ ya da $5 \mathrm{~g} / \mathrm{cm}^{3}$ 'ten fazla olan metaller ağır metal olarak adlandırılmaktadır. Buna karşın, arseniğin özgül ağırlığı bu değerlerden az olmasına rağmen ağır metaller gibi toksik etki gösterdiğinden, ağır metallerin arasında yer almaktadır (Aslam vd., 2013).

Ağır metaller genellikle yerkabuğunda doğal olarak, doğal sularda eser miktarlarda bulunan, ancak çoğu çok düşük konsantrasyonlarda bile toksik olan yapılardır (Şekil 1) (Herawati vd., 2000; Masindi \& Muedi, 2018). Bulundukları ortamlarda kolaylıkla bozulmaz ve yok edilemez özelliklere sahiptirler. Uzun süre deformasyona uğramadan alıcı ortamda kalabilmeleri, bulundukları ortamdaki canlıların bünyesinde birikerek besin ağ yoluyla diğer canlılara aktarılabilmeleri, doğal kaynakların yanı sıra artan antropojenik baskılar (kentsel ve endüstriyel baskılar, yayılı kaynaklı baskılar, jeotermal kaynaklı baskılar) ile kolaylıkla sucul ekosistemlere ulaşabilmeleri bu problemin önemini tanımlar niteliktedir (Aras vd., 2017). Sucul alanda veya sedimentte var olan kirliliğin mekansal ve zamansal değişimini anlamak; çevre bilimcileri, sucul alan yöneticileri, atık su çalışanlarının olduğu kadar halkın da ilgisini çekmektedir (Karadavut vd., 2012b; Vane vd., 2020). Çünkü tek başına veya bir arada olan metallere ilaveten bileşikler halinde de bulunabilen metalik yapıların, ekosistem sağlığı üzerinde olumsuz etkileri, yapılan birçok çalışmada ortaya konmuştur (Kalıpcı vd., 2017). Sadece insan sağlı̆̆ açısından düşünülmemesi gereken ekosistemleri etkileyen ağır metal kirliliğinin, sürekli izlenmesi, sonuçların değerlendirilmesi ve yorumlanması gerekmektedir.

Genellikle, antropojenik aktivitelerden kaynaklı önemli olan ağır metallerin başında kadmiyum $(\mathrm{Cd})$, krom $(\mathrm{Cr})$, bakır $(\mathrm{Cu})$, demir $(\mathrm{Fe})$, kurşun $(\mathrm{Pb})$, civa $(\mathrm{Hg})$, nikel (Ni), gümüş $(\mathrm{Ag})$, kalay $(\mathrm{Sn})$, çinko $(\mathrm{Zn})$ ve arsenik (As) gelmektedir (Yücel \& Yücel, 2013; Vane vd., 2020). Ancak doğada tek başlarına bulunmalarından ziyade, genelde hidroksitler, oksitler, sülfitler, sülfatlar, fosfatlar, silikatlar ve organik bileşikler şeklinde karşılaşılmaktadır. Sucul kaynaklarımızda artan ağır metal miktarı şu anda daha büyük bir endişe konusudur ve bilinen odur ki, çok sayıda endüstri, metal içeren atık sularını yeterli olmayan arıtma ile tatlı sulara deşarj etmektedir.

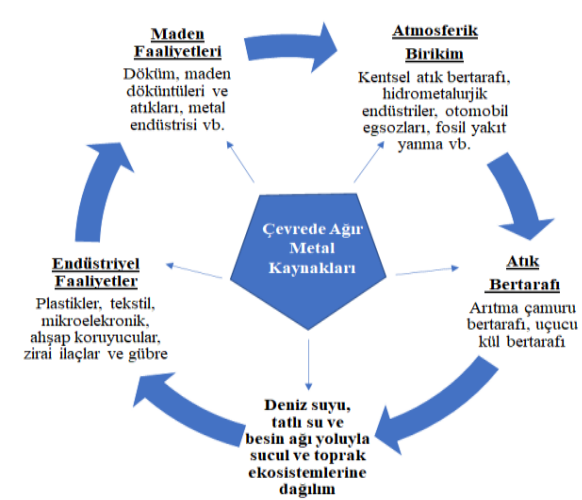

Şekil 1. Ağır metal kaynakları ve doğada dağılımları (Çelebi \& Gök (2018)'den uyarlanmıştır).

Figure 1. Heavy metal sources and their distribution in environment (adapted from Çelebi \& Gök (2018).

Her ülkede olduğu gibi ülkemizde de su kalitesinin korunması ve su kirlenmesinin önlenmesi amacıyla yönetmelikler oluşturulmakta ve denetimler yönetmeliklerde belirtilen esaslar doğrultusunda yapılmaktadır. Yer altı ve yerüstü su kaynakları potansiyelinin kullanım amacı gözetmeksizin korunmasını ve su kirliliğinin önlenmesini sağlamak amaciyla tüm kurum ve kuruluşlar, ilgili yönetmeliklerde belirlenen hükümlere uymak ve bunları uygulamakla yükümlüdür (Çevre ve Şehircilik Bakanlığı, 2017). Bu amaçla, akademik çalışmaların takibi ve değerlendirilmesi, tüm ülkelerde önem arz etmektedir (Cole, 2003).

Akademik yayınların çeşitli unsurlarının sayısal analizler ve istatistikler yardımıyla incelenmesi ve bu incelemelerin sunum yöntemleri ile ilgilenen "Bibliyometri", tanımlama, değerlendirme ve araştırmanın izlenmesi şeklinde de ifade edilebilmektedir (Ellegaard \& Wallin, 2015). Esas olarak bibliyometri, bilimsel çalışmaların, yazar, basılan dergi, konu, anahtar kelimeler, atıf yapılan yazar, atıf yapılan kaynaklar gibi verilerin istatistiksel olarak incelenmesi ile elde edilen sonuçlar doğrultusunda belirli bir disipline ait genel yapının ortaya konmasını mümkün kılmaktadır (Zan, 2012). Değerlendirme yöntemi olarak kullanıldı̆̆ında, teknolojinin etkisi veya bir yazarın, organizasyonun araştırmanın etkinliğini belirlemeye yardımcı olmaktadır (Van Raan, 2014). Aynı zamanda, izleme aracı olarak işlev görür ve zaman içerisinde araştırma alanının etkinlik düzeyini izleyebilmek için kullanılabilir (Levac vd., 2010).

$\mathrm{Bu}$ çalışmada amaç, Türkiye'de tatlı su (göl, nehir, akarsular, haliç gibi) ve deniz suyu karakteri taşıyan yüzey sularında, 2000-2020 yılları arasında yayınlanan "ağır metal" ile ilgili araştırmaların bibliyometrik analizini yapmaktır. Bu amaçla, uluslararası nitelikli bilimsel dergilerde yayınlanmış, Türkiye sucul alanlarında "yerinde örnekleme" ardından yapılan ağır metal analizlerini içeren çalışmalar bibliyometrik yöntemle ağ analizleri kullanılarak yorumlanmıştır. 


\section{METODOLOJi}

$\mathrm{Bu}$ çalışmada, 5.000'den fazla yayıncının yayınladığı 20.000'den fazla hakemli dergiyi kapsayan ve akademik dergi makalelerinin bibliyografik veri tabanı olan Scopus arama motoru kullanılmıştır (Blettler vd., 2018). Scopus arama motorunda, 2000-2020 y1llar1 arasında sucul ortamlarda ağır metal çalışmaları adına yapılan araştırmalar incelenmiştir. Arama yapılırken kullanılan anahtar kelimeler, "sea water (TR: deniz suyu)", "freshwater (TR: tatll su)", "heavy metal (TR: ăgır metal)", "Turkey (TR: Türkiye)" olarak sıralanmıştır. Kullanılan anahtar kelimeler arama motoru dilinden dolayı İngilizce olup, çalışmada bundan sonra Türkçe karşılıkları ile ifade edilmiştir. Yüzeysel su ortamlarında, kısıtlayıcı anahtar kelimeleri kullanarak 2 farklı sınırlı arama yapılmıştır. Bu farkı, çalışılan yüzeysel su ortamları oluşturmaktadır. Buna göre; yapılan ilk arama "deniz suyu", "ă̆ır metal", "Türkiye" anahtar kelimelerinden, ikinci arama ise, "tatlı su", "ağır metal", "Türkiye" anahtar kelimelerinden oluşmaktadır. Tatlı su ortamlarında yürütülen ağır metaller ile ilgili çalışmalar için göl, lagün, akarsu, dere, nehir anahtar kelimeleri ile kategorizasyon yapılmıştır.

$\mathrm{Bu}$ çalışma kapsamında, uluslararası nitelikte dergilerde yayınlanan her araştırma makalesi, (i) çalışıldığ ortam (deniz, göl, nehir, yeraltı suyu, rezervuar suyu, baraj vb.), (ii) ağır metal analiz metodu, (iii) analizi yapılan ağır metaller, (iv) makalenin yayınlandığı dergi, (v) basım yılı ve (vi) araştırma yapılan bölgeye göre kategorilere ayrılmıştır. Bibliyometrik analizler ile çalışmadan elde edilen sayisal veriler, Microsoft Excel programı kullanılarak yorumlanmış ve VOSViewer üzerinden yapılan sosyal ağ analizi haritaları ile görselleştirilmiştir.

\section{SONUÇ VE TARTIŞMA}

Bu çalışmada, 2000-2020 yılları arasında, ağır metal ile ilgili Türkiye'deki sucul alanlarda, yerinde örnekleme ardından yapılan araştırmalar kategorize edilmiş ve bibliyometrik analizlerden elde edilen bulgular, tablo ve şekillerle görselleştirilmiştir. Elde edilen bulgular öncelikle, (i) yayın ölçütleri (basım yılı, makalenin yayınlandığı dergi ve araştırmanın yapıldığı yer (bölge)), (ii) metodoloji ölçütleri (ağır metalin çalışıldığı sucul ortam, ağır metal analiz metotları ve analizi yapılan ağır metaller) ve (iii) makalelerin iş birlik ilişkileri (VOSviewer) başlıkları altında irdelenmiştir.

Çalışmalarda Tercih Edilen Yayın Ölçütleri: Scopus veri tabanında yapılan araştırmalarda, sadece son 20 yılda (2000-2020), su kalitesinin önemli başlıklarından biri olan, "ağır metal" ile ilgili küresel araştırma eğilimleri dikkate alındığında, toplamda 1661 doküman bilimsel çalışma tespit edilmiştir. Anahtar kelime olarak "deniz suyu", "ă̆ır metal" ve "Türkiye" seçildiğinde, anabilim dalı ayırt etmeksizin tüm başlıklara ait veri sonuçlarında toplam 58 doküman görüntülenmektedir. Anahtar kelime olarak "tatlı su", "ă̆ır metal" ve "Türkiye" kullanıldığında ise, sucul alanlarda yapılan çalışmalara ait toplam 56 doküman belirlenmiştir. Ayrıca, iki dokümanda yerinde örnekleme sonrası ağır metal tayini yapılmış (1 adet makale Kuzey Kıbrıs, 1 adet makale Hindistan'da olmak üzere), ancak Türkiye sucul alanlarında çalışılmadığı için değerlendirmeye alınmamıştır. $\mathrm{Bu}$ dokümanlardan bir tanesinin konferansta sunulan bildiri olduğu, bir makalede de her iki anahtar kelime ("deniz suyu" ve" tatlı su") içeren ortak çalışma olduğu tespit edilmiştir. İki farklı sucul alan araştırmasına ait toplamda 111 doküman incelenmiştir. İncelenen dokümanların arasında ancak 48 adet araştırma makalesinin, sucul alandan örneklenerek alınan su örneklerinde ağır metal tayini gerçekleştirildiği tespit edilmiştir. "Deniz suyu" ve "tatlı su" sucul alanlarında yerinde alınan su örneklerinde ağır metal tayini gerçekleştirilen çalışmalar sırasıyla Tablo 1 ve Tablo 2'de verilmiştir. Çalışma alanı sütununda incelenen makalelerde tespit edilen anahtar kelimeler, aslına uygun olarak özellikle İngilizce terimlerle sunulmuştur.

Sucul alandan alınan su örneklerinde ağır metal tayini gerçekleştirilen araştırma makalelerinin, yıllara göre dağılımı Şekil 2'de verilmiştir. 2006 yılından itibaren bu konuya artan bir eğilimin olduğu görülmektedir. 2013'ten 2020 yılına kadar toplam makale sayısı 27'ye ulaşmıştır. 2006-2013 ve 2014-2020 periyotları araştırmacıların yayınladıkları makale sayıları benzer karakteristiğe sahiptir. Bu periyotlarda 2011 ve 2017 yıllarında makale sayısı maksimum değere ulaşmıştır. Ancak 2006 ve 2014 yıllarında sadece birer adet makaleye rastlanmıştır.

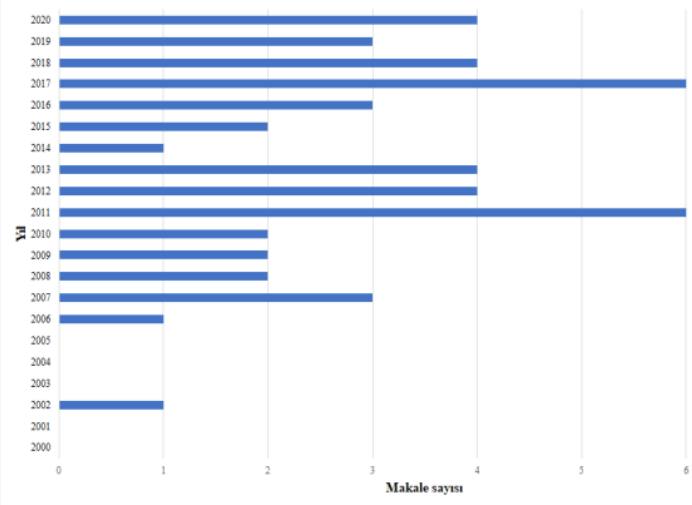

Şekil 2. 2000-2020 yılları arasında yayınlanan toplam makale sayis1.

Figure 2. Total number of articles published between 20002020.

Türkiye özelinde, 2000-2020 y1lları arasında sucul alandan alınan su örneklerinde ağır metal tayini gerçekleştirilen makalelerin en çok yayınlandığ 
disiplin alanları ve dergilerin çeyrek kategorileri (Q değeri) Tablo 3'te verilmiştir. Bilimsel dergilerin değerlendirmesinde, yararlanılan çeyrek kategorisi dört kategoriden oluşmakta ve Q1 en yüksek kategoriyi, Q4 ise en düşük kategoriyi ifade etmektedir. Makalelerin daha çok düşük dilimli, Q3 ve Q4 çeyrek dilimlerindeki dergilerde yayınlandığı görülmektedir. Dergiler arasında, "Environmental Monitoring and Assessment" ilk sirada yer almakta olup, "Marine Pollution Bulletin" ve "Fresenius Environmental Bulletin" dergileri bu siralamayı takip etmektedir.

Tablo 1. "Deniz suyu" anahtar kelimesi kullanılarak yayınlanan makaleler (Çalışma alanı, arama yapılan dilde sunulmuştur).

Table 1. Manuscripts published using the keyword "seawater" (Study area presented in searched language).

\begin{tabular}{|c|c|c|c|c|}
\hline Yil & Şehir & Makalenin Yayınlandığı Dergi & Referans & Çalışma Alanı \\
\hline 2019 & Kastamonu-Bartın & Indian Journal of Geo-Marine Sciences & Gokkus \& Berber, 2019 & Port (seawater), sediment, organism (Mytilus galloprovincialis) \\
\hline 2019 & Hatay - Adana & Fresenius Environmental Bulletin & Duysak, 2019 & Bay \\
\hline 2018 & Samsun - Sinop - Ordu & Global Nest Journal & Ustun vd., 2018 & Seawater \\
\hline 2017 & Muğla & $\begin{array}{l}\text { Bulletin of Environmental Contamination and } \\
\text { Toxicology }\end{array}$ & Genç \& Yilmaz, 2017 & $\begin{array}{l}\text { Seawater- lagoon system, sediment, Organism (Callinectes sapidus, } \\
\text { Mugil cephalus and Anguilla anguilla) }\end{array}$ \\
\hline 2017 & Giresun - Trabzon - Rize - Artvin & Marine Pollution Bulletin & Baltas vd., 2017a & $\begin{array}{l}\text { Seawater, sediment, organism (Mytilus galloprovincialis, Rapana } \\
\text { venosa) }\end{array}$ \\
\hline 2017 & İzmir & $\begin{array}{l}\text { Environmental Science and Pollution } \\
\text { Research }\end{array}$ & $\begin{array}{l}\text { Aydın-Önen \& Öztürk, } \\
2017\end{array}$ & $\begin{array}{l}\text { Seawater -bay, harbour, sediment, organism (Patella } \\
\text { caerulea, Cystoseira barbata and Liza aurata) }\end{array}$ \\
\hline 2016 & Giresun & Fresenius Environmental Bulletin & Polat \& Akkan, 2016 & seawater \\
\hline 2015 & Antalya & Indian Journal of Geo-Marine Sciences & Tekin-Özan, 2015 & Seawater, bay, sediment \\
\hline 2013 & Mersin & Jeoloji Muhendisliği Dergisi & Demir \& Özdemir, 2013 & Water -stream, sea, wells, soil, plant \\
\hline 2013 & Kocaeli & Marine Pollution Bulletin & Bingöl vd., 2013 & Seawater -stream, bay \\
\hline 2013 & Kocaeli & Marine Pollution Bulletin & Ergül vd., 2013 & Seawater -gulf \\
\hline 2012 & Antalya & Journal of Animal and Plant Sciences & Aktan \& Tekin-Özan,2012 & Seawater -bay- organism (Scomber japonicus, scomber scombrus) \\
\hline 2011 & Çanakkale, İzmir, Muğla & Marine Pollution Bulletin & $\begin{array}{l}\text { Akcali \& Kucuksezgin, } \\
2011\end{array}$ & Seawater, sediment, organism(macroalgae species) \\
\hline 2011 & İzmir - Aydın & Marine Pollution Bulletin & Aydin Onen vd., 2011 & Seawater, sediment, organism (Amphibalanus amphitrite) \\
\hline 2011 & Çanakkale & Environmental Monitoring and Assessment & Ustunada vd., 2011 & Seawater, organism $(U$. rigida $)$ \\
\hline 2011 & Çanakkale & Environmental Monitoring and Assessment & Y1lmaz \& Sadikoglu, 2011 & Seawater -strait- \\
\hline 2010 & Muğla & Environmental Monitoring and Assessment & Balkis vd., 2010 & Seawater -bay, sediment \\
\hline 2009 & İstanbul & Environmental Monitoring and Assessment & Altug \& Balkis, 2009 & Seawater -estuary, sediment, organism (Enterobacteriaceae) \\
\hline 2007 & Mersin & $\begin{array}{l}\text { Bulletin of Environmental Contamination and } \\
\text { Toxicology }\end{array}$ & Karayakar vd., 2007 & Seawater, Organism (Brachidontes pharaonis ) \\
\hline 2007 & Çanakkale & Environmental Monitoring and Assessment & Süren vd., 2007 & Seawater-strait \\
\hline
\end{tabular}

Çalışmaların, bölgesel olarak yayınlanan makale sayılarına ait dağılımı Şekil 3'te verilmiştir. Çalışmaların genellikle "su kalitesi” başlığında yapılmış ancak "sucul ortamda ă̆ır metal analizi” içermiyor olması nedeniyle, bu çalışma için kabul edilmemiştir. Makalelerin bazılarında ise, birden fazla bölgede çalışma yapıldığı için, ilgili makaleler her iki bölgenin makale sayısına eklenmiştir. Buna göre, uluslararası nitelikte dergilerde en çok yayınlanan makale sayısına göre çalışmaların yapıldığı bölgeler sirasıyla Karadeniz (\%28), Ege (\%20), Doğu Anadolu (\%18), Marmara (\%17) ve Akdeniz (\%13) bölgeleridir. Çalışma kapsamında incelenen yayınların, Türkiye'nin farklı bölgelerindeki üniversiteler tarafından yürütüldüğü görülmektedir. İç Anadolu ve Güneydoğu Anadolu bölgelerinde ise, sucul alanların sınırlı oluşundan da kaynaklanan kısıtlı sayıda çalışma yürütülmüştür. Doğu Anadolu Bölgesi'nde çalışmalar daha çok tatlı su ve baraj göllerinden alınan örneklerde yapılmış; veriler su kimyası ve kalitesi özelinden ziyade, sağlık riski analizi özelinde irdelenmiştir. Şehirlerde yürütülen çalışmalar açısından en çok dikkati çeken il Muğla olmuştur.

\section{Çalışmalarda Seçilen Metodoloji Ölçütlerine}

Göre Durum Değerlendirilmesi: Çalışmalarda seçilen ağır metalin çalışıldığ 1 sucul ortam, ağır metal analiz metotları ve analizi yapılan ağır metaller ölçütlerine göre değerlendirilme yapılmıştır. Buna göre, ağır metal çalışmalarının gerçekleştirildiği sucul alanların dağılımı Şekil 4'te verilmiştir. Şekilde görüldüğü üzere, sucul alanların \%27'lik bölümünü, denizel ortamdan alınan su örneklerde ağır metal tayinin gerçekleştirildiği çalışmalar oluşturmaktadır. Geriye kalan çalışmalar, tatlı su karakteristiğine sahip sucul ortamlarda yürütülmüş çalışmalardır. Tatlı su ortamlarında, nehir suyu örnekleri tüm çalışmalar içinde \%21'lik bölüme denk gelmektedir. Ağır metallerin yüzeysel sulara taşınmasında rol oynayan etkenlerin arasında yüzeysel akış, evsel ve endüstriyel deşarjlar, maden faaliyetleri ve atmosferik taşınım yer almaktadır. Noktasal kaynak olarak deşarjların yanı sıra, ağır metallerin karayollarından, kentsel alanlardan yayılı kirletici kaynak olarak yüzeysel akış ile denizel ya da tatlı su alıcı ortamlarına ulaştığı tespit edilmiştir (Dereli vd., 2017).

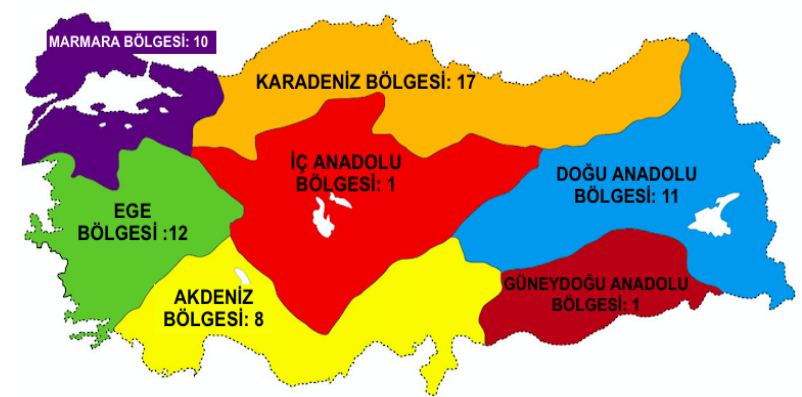

Şekil 3. Bölgelere göre uluslararası nitelikte dergilerde yayınlanan makale sayısı.

Figure 3. Number of manuscripts published in international journals according to regions.

Sucul alanlarda yapılan ağır metal çalışmalarda hedef genellikle ağır metal kontaminasyon ve sucul organizmalardaki birikiminin incelenmesidir. Yapılan çalışmalarda, sadece sucul ve/veya sediment ortamlardan alınan örneklerde kantitatif sonuçlar elde edilmekle sınırlı kalmayıp, organizmalar üzerindeki biyolojik ve ekotoksikolojik etkilerin tespiti üzerine de oldukça fazla çalışmaya rastlanmıştır (Aydın -Önen \& Öztürk, 2017; Baltas vd., 
2017; Dane \& Șișman, 2020a; Dane \& Șișman, 2020b; Genç \& Yılmaz, 2017; Ustunada vd., 2011). Sucul alanlarda "ağır metal", "deniz suyu", "tatl su" anahtar kelimelerinin yer aldığı ilgili çalışmalarda, "sediment" ve "balık" anahtar kelimeleri de tercih edilmiştir (Akbulut \& Tuncer, 2011; Dane ve Şişman, 2020a; Dane ve Şişman, 2020b; Demirak vd., 2006; Tunca vd., 2013). Sedimentler özellikle bozunmaya dayanıklı kirleticilerin su kolonundan çok daha yüksek konsantrasyonlarda bulunma ihtimallerine karşıllı, kirleticilerin izlenmesi için hassas gösterge olabilir. Sucul ortamlara kentsel, endüstriyel ve tarımsal faaliyetlerden kaynaklanan farklı kimyasalları taşıyan karasal girdiler aracılığıyla, sedimentte başta ağır metaller olmak üzere çeşitli tehlikeli ve toksik maddeler birikim yapmaktadırlar (Bakan \& Özkoç, 2007). Balıklar ise, doğrudan adsorpsiyon veya besin zincirleri yoluyla ağır metalleri biriktirebildiği ve tüketim yoluyla insanlara geçerek kronik veya akut hastalıklara neden olduğu bilinmektedir (Baltas vd., 2017; Calza vd., 2004). Ağır metal tayinlerinin genellikle "deniz suyu" ve "nehir" sucul ortamlarında yoğunlaştığı Karadeniz Bölgesi'nde gerçekleştirilen çalışmalarda da benzer duruma rastlanılmıştır (Baltas vd., 2017a; Baltas vd., 2017b; Verep vd., 2012). Özellikle, Ege ve Akdeniz Bölgesi'nde "deniz suyu" ortamında yürütülen çalışmalarda, midye gibi diğer sucul organizmalarda yapılan biyobirikim incelemeleri de dikkat çekmektedir (Aydın-Önen vd., 2011; Karayakar vd., 2007). Tıpkı, balıklar gibi midyeler de ekotoksikolojik ve biyobirikim gibi biyodeneylerde sıklıkla tercih edilen organizmalardır. $\mathrm{Bu}$ organizmalar, suyu süzerek beslendikleri ve/veya süzerek beslenen canlılarla beslendikleri için, ağır metaller ve diğer ksenobiyotik bileşikleri kolaylıkla bünyelerine alabilmektedirler. Biyoindikatör ve biomonitor tür olarak öneme sahip olan bu türler (özellikle Mytilus galloprovincialis) akuatik sistemlerde metalleri bünyelerinde biriktirebilirler (Dökmeci vd., 2012).

Tablo 2. "Tatlı su" anahtar kelimesi kullanılarak yayınlanan makaleler (Çalışma alanı, arama yapılan dilde sunulmuştur).

Table 2. Manuscripts published using the keyword "freshwater" (Study area presented in searched language).

\begin{tabular}{|c|c|c|c|c|}
\hline Yil & Şehir & Makalenin Yayınlandığı Dergi & Referans & Çalışma Alanı \\
\hline 2020 & Muğla & Arabian Journal of Geosciences & Arslan \& Avşar, 2020 & Lake \\
\hline 2020 & Elazığ/ Tunceli & Environmental Research & Canpolat vd., 2020 & Keban Dam Lake/Freshwater \\
\hline 2020 & Erzurum & Chemosphere & Dane \& Sisman, 2020a & $\begin{array}{l}\text { Karasu River/ Organism (Capoeta capoeta, Alburnus mossulensis and } \\
\text { Squalius cephalus), sediment, Freshwater }\end{array}$ \\
\hline 2020 & Erzurum & Turkish Journal of Veterinary and Animal Sciences & Dane \& Şişman, 2020b & Karasu River/ Organism (Alburnus mossulensis), sediment, Freshwater \\
\hline 2019 & Elazı̆̆ & Chemosphere & Varol, 2019 & Keban Dam Reservoir/ Freshwater \\
\hline 2018 & Aydın/Denizli & Applied Ecology and Environmental Research & Minareci vd., 2018 & Buyuk Menderes River/ Freshwater \\
\hline 2018 & Sinop & Global Nest Journal & Aydin Uncumusaoğlu, 2018 & Bektaş Pond/Freshwater \\
\hline 2018 & Elazığ & Science of the Total Environment & Varol \& Sünbül, 2018 & $\begin{array}{l}\text { Keban Dam Reservoir/ Organism (Mangar, common carp, Tigris scraper, } \\
\text { Euphrates barbell and trout barb), Freshwater }\end{array}$ \\
\hline 2017 & Rize & Marine Pollution Bulletin & Baltas vd., 2017b & seaeater -river- harbour, sediment, Organism(Engraulis encrasicolus) \\
\hline 2017 & Erzurum & Turkish Journal of Zoology & Dane \& Şişman, 2017 & Karasu River/freshwater, Organism(Chub sp.) \\
\hline 2017 & Bingöl & Environmental Science and Pollution Research & Demir \& Sahin, 2017 & treated waste water/ Freshwater \\
\hline 2016 & Kocaeli & Environmental Earth Sciences & Yolcubal vd., 2016 & Groundwater, surface water -river \\
\hline 2016 & Gaziantep & Ecotoxicology and Environmental Safety & Çelekli vd., 2016 & $\begin{array}{l}\text { Creek,Reservoir,Irrigation channel, River/freshwater, Organism } \\
\text { (filamentous algae) }\end{array}$ \\
\hline 2015 & Erzurum & Environmental Toxicology & Dane \& Şişman, 2015 & Karasu River/freshwater, Organism(Capoeta capoeta) \\
\hline 2014 & Malatya & Fresenius Environmental Bulletin & Canpolat vd., 2014 & Karakaya Dam Lake/Freshwater,Organism (Aspius vorax) \\
\hline 2013 & Bolu & Chemistry and Ecology & Tunca vd., 2013 & Lake Yeniçağ/Organism(Astacus leptodactylus) freshwater,sediment \\
\hline 2012 & Rize & Pakistan Journal of Biological Sciences & Verep vd., 2012 & İyidere strea/freshwater,sediment, Organism(freshwater fish species) \\
\hline 2012 & İstanbul & Environmental Monitoring and Assessment & Balc1 vd., 2012 & Lake Maslak/Freshwater, sediment, Organism(bacterial communities) \\
\hline 2012 & Kırşehir & Environmental Earth Sciences & Pasvanoğlu \& Gültekin, 2012 & Thermal water springs and wells/freshwater \\
\hline 2011 & Samsun & Water, Air, and Soil Pollution & Akbal vd., 2011 & Seawater, river \\
\hline 2010 & Bursa & Journal of Paleolimnology & Kazanci vd., 2010 & Lake Ulubat/freshwater, sediment \\
\hline 2009 & Elazı̆g & Fresenius Environmental Bulletin & Karadede-Akin, 2009 & $\begin{array}{l}\text { Hazar Lake/Freshwater, sediment, } \\
\text { Organism(Capoeta capoeta umbla) }\end{array}$ \\
\hline 2008 & Antalya & Micropaleontology & Meriç vd., 2008 & Antalya Coast/Submarine groundwater discharge, open sea \\
\hline 2008 & Hatay & Environmental Monitoring and Assessment & Y1lmaz \& Doğan, 2008 & Orontes River/ Freshwater, Organism (Carasobarbus luteus) \\
\hline 2007 & Samsun & International Journal of Environmental Studies & Bakan \& Özkoç, 2007 & $\begin{array}{l}\text { Marine and freshwater/Sediment, water, Organism } \\
\text { (Mytilus galloprovincialis) }\end{array}$ \\
\hline 2006 & Muğla & Chemosphere & Demirak vd., 2006 & Dipsiz stream/Freshwater,sediment, Organism (L. Cephalus) \\
\hline 2002 & İzmir & Environment International & Sponza \& Karaoğlu, 2002 & River, sediment, rock, soil \\
\hline
\end{tabular}

Sucul ortamlarda en çok çalışılan ağır metallerin yüzdelik dağıllımı Şekil 5'te verilmiştir. Buna göre, Türkiye sucul alanlarında yerinde örnekleme yapılan ağır metal analizlerini içeren makalelerin \%90'nında $\mathrm{Pb}$ ve $\mathrm{Cu}$ metalleri çalışılmıştır. Çalışılan bu ağır metallerden sonra, Cd (\%79) ve $\mathrm{Zn}(\% 75)$ metalleri gelmektedir. $\mathrm{Cu}, \mathrm{Zn}$ ve $\mathrm{Fe}$, organizmaların yaşamsal faaliyetleri için eser miktarlarda gerekli olmasına rağmen, bu metallerin yüksek konsantrasyonları ve $\mathrm{Cd}, \mathrm{Hg}$ ve $\mathrm{Pb}$ gibi biyolojik fonksiyonları yaşamsal faaliyetler için gerekli olmayan ağır metaller dokularda birikime, organizmanın hasar görmesi ve ölümüne buna bağlı olarak sucul ekosistemlerin yapısında değişikliklere neden olmaktadır (Farayakar vd., 2007). Genel olarak, sucul organizmalarda $\mathrm{Pb}$ birikimi ve sonrasında besin ağı yoluyla tüketimi, özellikle kan oluşumu, kemik ve sinir sistemi üzerinde ciddi etkileri mevcuttur (Süren vd., 2007). Çalıșmalardaki ağır metal birliktelikleri incelendiğinde, çalıșma ortamı, çalışma bölgesi ve ağır metallerin kendi aralarındaki ilişkileri göz önüne alınmalıdır. Örneğin, deniz suyunda $\mathrm{Pb}$ ve $\mathrm{Cu}$ metallerinin birlikte çalışılmasının nedeni, bu ağır metallerin balast suları ve antifouling boyalardan kaynaklı etkilerinin belirlenmesi olabilir (Purwiyanto vd., 2020). Çalışma bölgesinin jeolojik yapısına bağlı olarak ise, Doğu Karadeniz Bölgesi'nde kompleks $\mathrm{Cu}, \mathrm{Zn}$ ve $\mathrm{Zn}$ cevherlerinin birlikte bulunması örneği verilebilir. Ağır metallerin birbirleri olan ilişkisi düşünüldüğünde ise $\mathrm{Cd}$, başta $\mathrm{Zn}$ olmak üzere Fe'in vücutta emilimini engeller ve $\mathrm{Cd}, \mathrm{Zn}$ 'nun yerini alabilmektedir. Cd ve Zn'nun çalışmalardaki birlikteliği diğer ağır metallerden farklı olarak birbirlerinin yerini alabilme özelliğinden kaynaklandığı düşünülmektedir. En az çalışılan ağır metaller ise, $\mathrm{Al}(\% 23)$ ve $\mathrm{Hg}(\% 21)$ olmuştur.

Makalelerin İş Birlik İlişkileri: Bu çalışmada, Scopus arama motorunda anahtar kelime olarak "deniz suyu", "ă̆ır metal", "Türkiye" ve "tatl su", "ağır metal", "Türkiye" seçildiğinde, bulunan makalelerin (yerinde örnekleme ile yapılan ağır metal analizleri farkı gözetmeksizin) tüm anahtar kelimeleri ile çalışmalar arasında işbirlik ilişkileri ortaya konulmaya çalışılmıştır. Makalelerde tercih edilen anahtar kelimeler üzerinden makalelerin işbirlik ilişkileri VOSviewer analizi sayesinde tespit edilip yorumlanmıştır. 
Tablo 3. İlgili makalelerin en çok yayınlandığı dergiler ve dergi etki faktörleri.

Table 3. Journals with the most published related manuscripts and journal impact factors.

\begin{tabular}{l|c|l|c}
\hline Disiplin Alanı & Sira & Derginin Adı & Kategori (Q) \\
\hline \multirow{5}{*}{ Çevre Bilimleri } & 1 & $\begin{array}{l}\text { Environmental Monitoring and } \\
\text { Assessment }\end{array}$ & Q3 \\
\cline { 2 - 4 } & 2 & Marine Pollution Bulletin & Q2 \\
\cline { 2 - 4 } & 3 & Fresenius Environmental Bulletin & Q1 \\
\cline { 2 - 4 } & 4 & Chemosphere & Q4 \\
\cline { 2 - 4 } & 5 & Global Nest Journal & $\begin{array}{l}\text { Bulletin of Environmental Contamination } \\
\text { and Toxicology }\end{array}$ \\
\cline { 2 - 4 } & 7 & $\begin{array}{l}\text { Environmental Science and Pollution } \\
\text { Research }\end{array}$ & Q3 \\
\hline & 8 & Environmental Earth Sciences & Q3 \\
\hline \multirow{2}{*}{ Oşinografi } & 9 & Indian Journal of Geo-Marine Sciences & Q4 \\
\hline
\end{tabular}

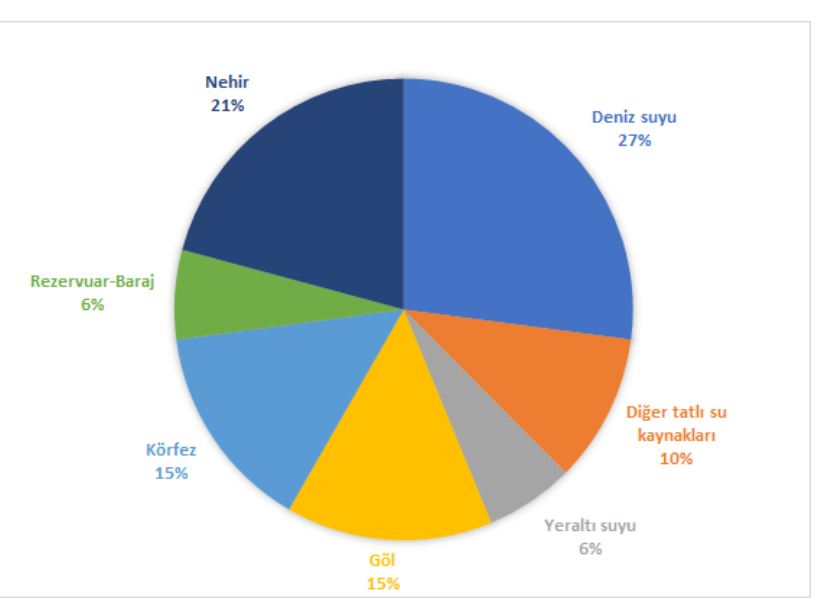

Şekil 4. Ağır metal çalışmalarının yapıldığı sucul ortamların yüzdelik dağılımı (\%).

Figure 4. Percentage distribution of aquatic environments where heavy metal studies were carried out (\%).

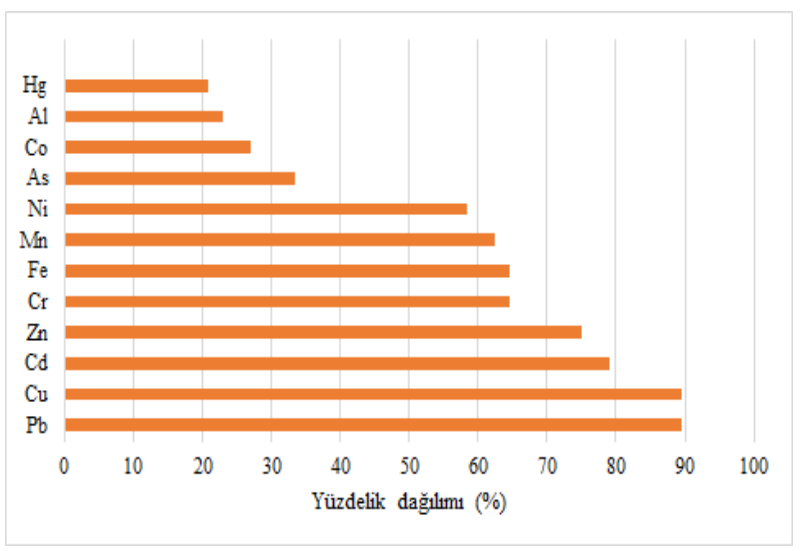

Şekil 5. Sucul ortamlarda analizi yapılan ağır metallerin çalışma sayılarına göre yüzdelik dağılımı (\%).

Figure 5. Percentage distribution of heavy metals analysis in aquatic environments according to the number of studies $(\%)$.

Türkiye'deki araştırmacıların, deniz suyunda yürüttükleri ağır metal çalışmaları başlığında, en sık kullandığı anahtar kelimeler ile çalışmalar arasında iş birlik ilişkileri Şekil 6'da gösterilmektedir. En yoğun kullanılan kelimelerin "heavy metal (TR:ăglr metal)", "heavy metals (TR:ă̆ır metaller)" ve "sediment (TR:sediment)" olduğu görülmektedir. Diğer anahtar kelimeler arasındaki bağlantılar özellikle farklı renklerle gösterilmiştir. " $A \breve{g} ı r$ metaller" anahtar kelimesinin "toxicity (TR:toksisite)", "Marmara Sea (TR:Marmara Denizi)" ve "mussels (TR:midye)" anahtar kelimeleri ile olan bağlantısı, Marmara Denizi'nde yapılmış ağır metal çalışmalarında, ağır metallerin midyeler üzerindeki ekotoksikolojik etkilerine de yer verildiğini ifade etmektedir.

Denizel ortamda yapılan çalışmalarda, en sık kullanılan anahtar kelimeler ile çalışma alanları arasında ilişkilerin yıllara bağlı değişimi ise, Şekil 7'de gösterilmektedir. Dairelerin büyüklüğü bahsedilen kelimelerin sayısıyla, daireler arasındaki çizgilerin kalınlıkları ise çalışmalar arasındaki işbirliğinin seviyesi ile orantılıdır. Y1llara bağlı analizde ise, 2010-2020 y1lları arasında "deniz suyu" sucul ortamında yapılan çalışmaların sayısı (44 adet) dikkati çekecek kadar fazladır. Son dönemlerde ağır metal konusundaki araştırmalarda gözlenen artış, Karadeniz (Baltas 2017a; Polat \& Akkan, 2016) ve Ege Denizi'nde (Aydın Onen \& Öztürk, 2017; Minareci vd., 2018) yoğunlaşmıştır.

Türkiye'deki araştırmacıların, tatlı suda yürüttükleri ağır metal çalışmaları başlığında, en sık kullandığı anahtar kelimeler ile çalışmalar arasında iş birlik ilişkileri Şekil 8'de gösterilmektedir. En yoğun kullanılan kelimelerin "heavy metal (TR:ağır metal)", "heavy metals (TR:ăgır metaller)" ve "fish (TR:balık)" olduğu görülmektedir. "Ăgır metal" anahtar kelimesinin "fish (TR:balık)", "sediment (TR:sediment) ve "water (TR:su)" anahtar kelimeleri ile olan bağlantısı, tatlı su ortamlarında su ve sediment örneklerinde ağır metallerin ekotoksikolojik etkilerine de yer verildiğini ifade etmektedir (Dane \& Şişman, 2020a; Dane \& Şişman, 2020b).

Tatlı su ortamında yapılan çalışmalarda, en sık kullanılan anahtar kelimeler ile çalışma alanları arasında ilişkilerin yıllara bağlı değişimi ise, Şekil 9'da gösterilmektedir. Yıllara bağlı analizde 2010-2020 yılları arasında yapılan çalışma sayısı 40 adettir. Diğer ülkelerde yapılan çalışmalarla karşılaştırıldığında, çalışma sayısı ve sıklığı ile benzerliği dikkat çekmektedir. 


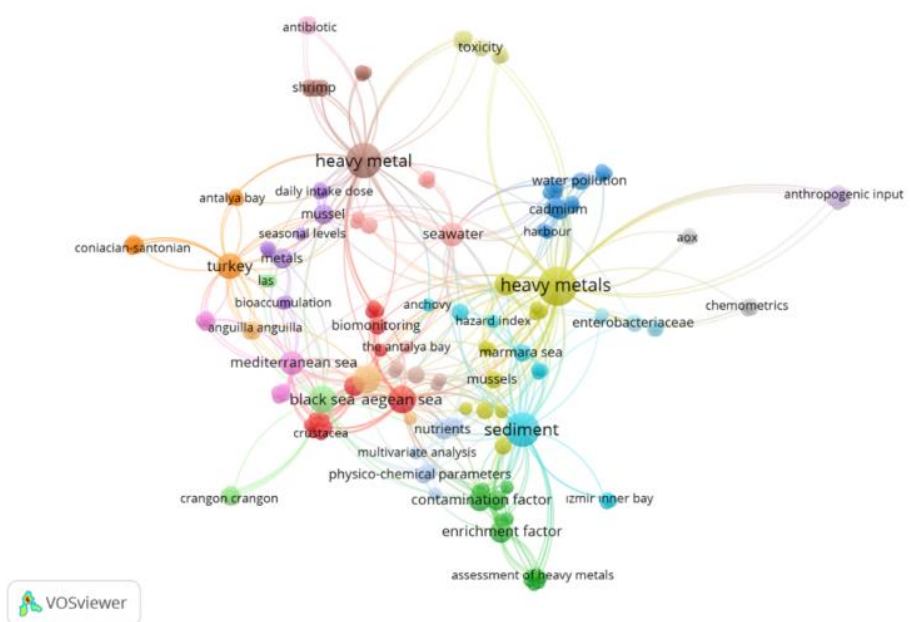

Şekil 6. Türkiye'deki araştırmacıların, deniz suyunda yürüttükleri ağır metal çalışmalarında en sık kullandığı anahtar kelimeler ile çalışmalar arasında iş birlik ilişkileri.

Figure 6. The most frequently used keywords in heavy metal studies conducted by researchers in Turkey in seawater and the collaborative relationships between the studies.

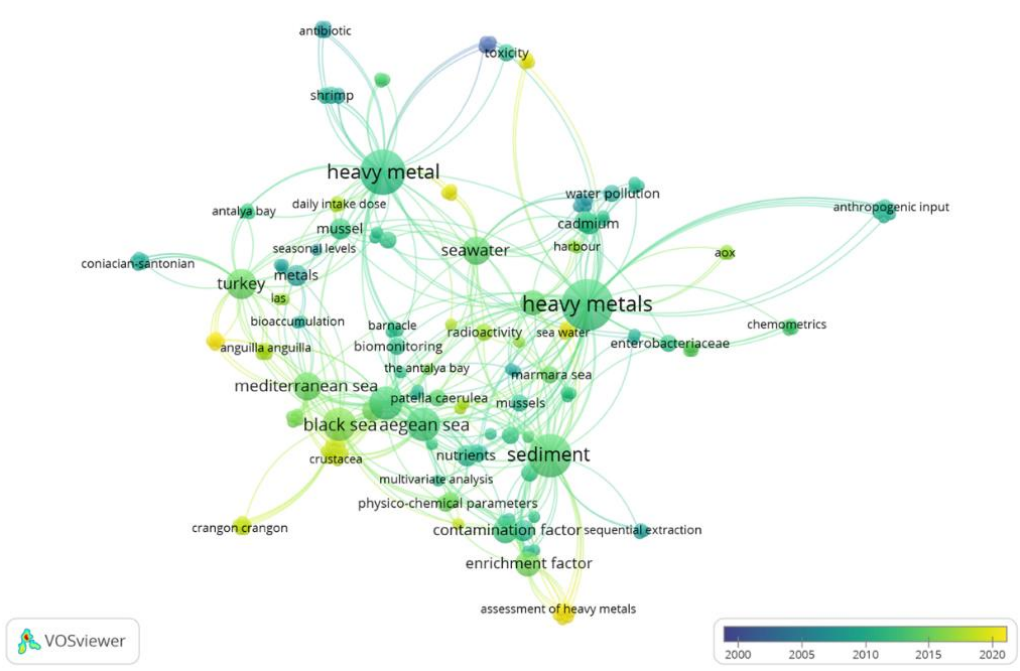

Şekil 7. Denizel ortamda yapılan çalışmalarda, en sık kullanılan anahtar kelimeler ile araştırma bölgeleri arasında iş birlik ilişkilerinin yıllara bağlı değişimi. Figure 7. The change over the years in the cooperation relations between the most frequently used keywords and research regions in studies conducted in the marine environment.

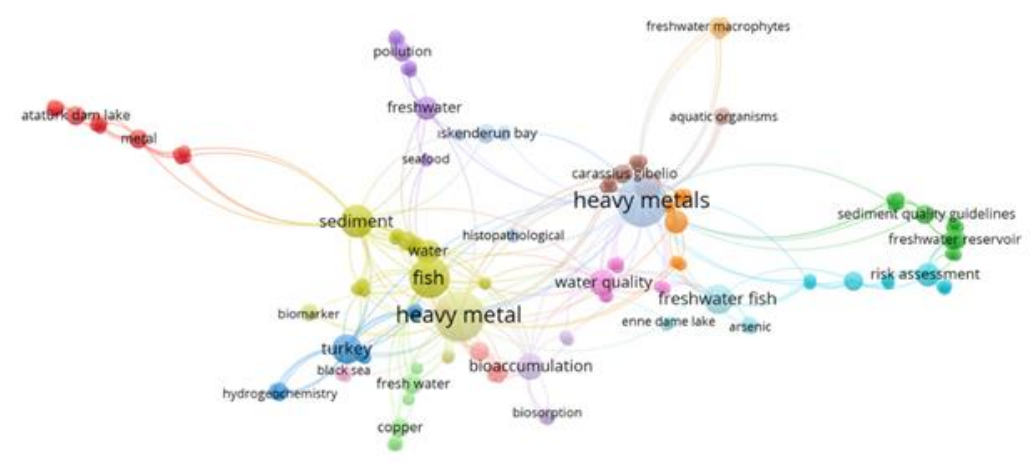

As vosviewer

Şekil 8. Türkiye'deki araştırmacıların, tatlı suda yürüttükleri ağır metal çalışmalarında en sık kullandığı anahtar kelimeler ile çalışmalar arasında iş birlik ilişkileri.

Figure 8. The most frequently used keywords in heavy metal studies conducted by researchers in Turkey in freshwater and the collaborative relationships between the studies. 


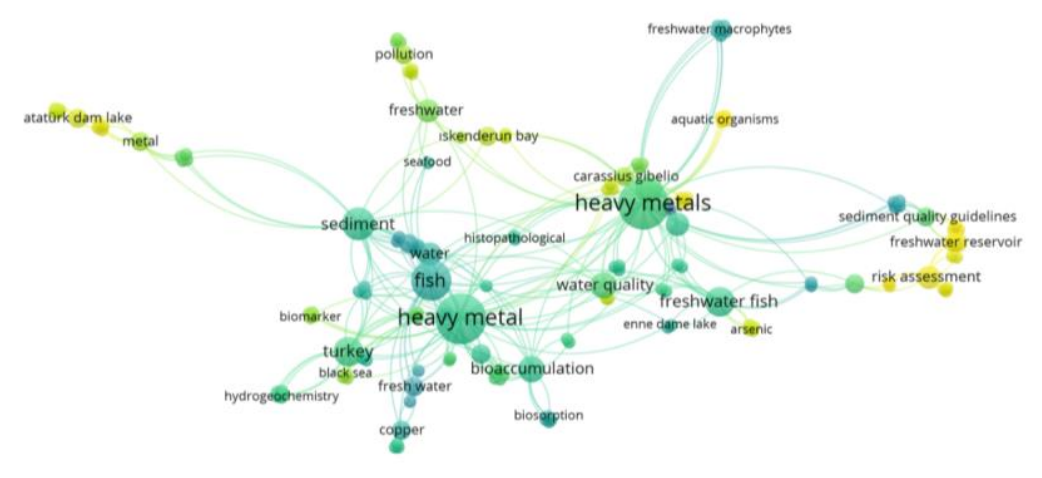

\& vosviewer

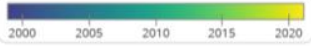

Şekil 9. Tatlı su ortamında yapıllan çalıșmalarda en sık kullanılan anahtar kelimeler ile araștırma bölgeleri arasında iș birlik ilişkilerinin yıllara bağlı değişimi. Figure 9. The change over the years in the cooperation relations between the most frequently used keywords and research regions in studies conducted in the freshwater environment.

\section{ÖNERILER}

Çalışmaya ait veriler incelendiğinde, yapılan bibliyometrik analiz sonucunda deniz suyu ve tatlı su anahtar kelimelerindeki çalışmalar incelenmiştir. İncelenen makalelerin sadece 48 tanesinde, sucul alanlarda yerinde örnekleme ardından ağır metal analizi çalışmaları yapıldığı tespit edilmiştir. Türkiye sucul ortamlarında yerinde örnekleme ile yapılan ağır metal analizlerini içeren çalışmalarının sınırlı olması, daha ziyade sentetik sularla laboratuvar ölçekli çalışma yapılması oldukça dikkat çekmiştir. Oysa, su sıkıntısı çekebilen bir konumda olan ülkemizde su kaynaklarını korumak, kirliliği önlemek/kontrolünü sağlamak için izleme-takip çalışmalarına daha fazla yer verilmesi ve ağır metal konsantrasyonlarına bağlı olarak farklı teknolojik yaklaşımlarla çözüm bulunmasının hedeflenmesi gerekmektedir.

Çalışmalarda kullanılan anahtar kelimeler genel ifadeler olarak kalmış özellikle "deniz suyu” anahtar kelimesinin altındaki makaleler çalışmalarda değerlendirilen sucul alanların niteliklerini doğru yansıtamamıștır. $\mathrm{Bu}$ durum yayınlanan makalelerin, anahtar kelime seçimlerinde oldukça sınırlı kaldığını göstermektedir.

$\mathrm{Bu}$ çalıșmaların yapıldığı sucul alanlardaki ağır metal konsantrasyonları ve maruziyetinin sağlık riski üzerindeki etkilerinin belirlenmesi ilke hedef olmalıdır. Çalışmalarda sucul alanlar tek unsurlarıyla incelenmeyip, genellikle alan hakkında kapsamlı sonuçlar elde edilmeye çalışılmıştır. Bu da bazı çalışmaların ağır metal kısmında sınırlı kalmasına neden olmaktadır. İleri analiz metotları ile yapılan ağır metal tayinleri maliyetli analizler olduğundan, dış kaynaklı projelerle desteklenmesi ve bütüncül yaklaşımlı çalışmalara konunun dahil edilmesi en sık rastlanan çalışma tipidir. Çalışmalarda ayrı bir beklenti de, biyolojik/ekotoksikolojik çalışmaların sonuçlarının yorumlanmasıdır. Ancak bu tip çalışmalar da hem zaman hem deneyim ve hem de maliyet gerektiren özel analizlerdir. Çok disiplinli bu çalışmaların tamamlanması yüksek bütçeli çalışmaların ve projelerin varlığı ile mümkündür. Sonuç güvenirliği açısından, doğru zaman ve bütçe yönetimi ile nitelikli çalışma ekipmanı ağır metal çalışmalarının temel özelliğidir. Sucul alanlardan numune alımından, numunelerin işlenmesi ve yorumlanmasına kadar her aşama özenle yapılmalıdır. $\mathrm{Bu}$ nedenle, su kalitesi izleme projeleri gibi genel çerçeveli projelerin devamlılığı, kalitenin sürdürülebilirliği, bütüncül çerçevede alanın izlenmesi ve korunması ile mümkündür.

\section{TEŞEKKÜR}

Yazarlar, bu makalenin hazırlanmasına temel olan "Küçükçekmece Lagünü Bağlantı Alanı Su ve Sediment Örneklerinde Ağır Metal Konsantrasyonlarının Tespiti" konulu TUBITAK-119Y302 nolu araştırma projesine verdiği destekten dolayı TUBITAK'a teşekkür ederler.

\section{KAYNAKLAR}

Akbal, F., Gürel, L., Bahadir, T., Güler, I., Bakan, G. \& Büyükgüngör, H. (2011). Multivariate statistical techniques for the assessment of surface water quality at the mid-Black Sea coast of Turkey. Water, Air, and Soil Pollution, 216(1-4), 21-37. DOI: 10.1007/s11270-010-0511-0

Akbulut, N.E. \& Tuncer, A.M. (2011). Accumulation of heavy metals with water quality parameters in Kızılırmak River Basin (Delice River) in Turkey. Environmental Monitoring and Assessment, 173(14), 387-395. DOI: 10.1007/s10661-010-1394-7

Akcali, I. \& Kucuksezgin, F. (2011). A biomonitoring study: Heavy metals in macroalgae from eastern Aegean coastal areas. Marine Pollution Bulletin, 62(3), 637645. DOI: 10.1016/j.marpolbul.2010.12.021 
Akduman, S., Demirbağ, M.A. \& Sivri, N. (2020). Bibliometric profile of scientific research on bacteriological water quality studies in Turkey (1999-2019). J. Anatolian Env. and Anim. Sciences, 5(3), 425-432. DOI: 10.35229/jaes.779012

Aktan, N. \& Tekin-Özan, S. (2012). Levels of some heavy metals in water and tissues of chub mackerel (Scomber Japonicus) compared with physicochemical parameters, seasons and size of the fish. Journal of Animal and Plant Sciences, 22(3), 605613.

Altug, G. \& Balkis, N. (2009). Levels of some toxic elements and frequency of bacterial heavy metal resistance in sediment and sea water. Environmental Monitoring and Assessment, 149(1-4), 61-69. DOI: 10.1007/s10661-008-0183-Z

Aras, S., Findik, O., Kalıpcı, E. \& Sahinkaya, S. (2017). Assessment of concentration physicochemical parameters and heavy metals in Kizılirmak river, Turkey. Desalination and Water Treatment, 72, 328334. DOI: $10.5004 /$ dwt.2017.20437

Arslan, Ş. \& Avşar, Ö. (2020). Assessment of heavy metal pollution in Köyceğiz-Dalyan coastal lagoon watershed (Muğla) SW Turkey. Arabian Journal of Geosciences, 13(15), 719. DOI: 10.1007/s12517020-05690-3

Aslam J, Khan SA \& Khan SH. (2013). Heavy metals contamination in roadside soil near different traffic signals in Dubai, United Arab Emirates. Journal of Saudi Chemical Society, 17, 315-319. DOI: 10.1016/j.jscs.2011.04.015

Aydın-Önen, S. \& Öztürk, M. (2017). Investigation of heavy metal pollution in eastern Aegean Sea coastal waters by using Cystoseira barbata, Patella caerulea, and Liza aurata as biological indicators. Environmental Science and Pollution Research, 24(8), 7310-7334. DOI: 10.1007/s11356-016-8226-4

Aydin Onen, S., Kucuksezgin, F. \& Kocak, F. (2011). Temporal and spatial biomonitoring of heavy metals in eastern Aegean coastal waters using Amphibalanus amphitrite. Marine Pollution Bulletin, 62(11), 2548-2556. DOI: 10.1016/j.marpolbul.2011.08.017

Aydin Uncumusaoğlu, A. (2018). Statistical assessment of water quality parameters for pollution source identification in Bektaş pond (Sinop, Turkey). Global Nest Journal, 20(1), 151-160. DOI: 10.30955/gnj.002369

Bakan, G. \& Özkoç, H.B. (2007). An ecological risk assessment of the impact of heavy metals in surface sediments on biota from the mid-Black Sea coast of Turkey. International Journal of Environmental Studies, $\quad 64(1), \quad 45-57 . \quad$ DOI: 10.1080/00207230601125069

Balcı, N., Vardar, N., Yelboga, E. \& Karaguler, N.G. (2012). Bacterial community composition of sediments from Artificial Lake Maslak, Istanbul, Turkey. Environmental Monitoring and Assessment, 184(9), 5641-5650. DOI: 10.1007/s10661-011$2368-0$

Balkis, N., Aksu, A., Okuş, E. \& Apak, R. (2010). Heavy metal concentrations in water, suspended matter, and sediment from Gökova Bay, Turkey. Environmental Monitoring and Assessment, 167(1-4), 359-370. DOI: $10.1007 / \mathrm{s} 10661-009-1055-\mathrm{x}$
Baltas, H., Kiris, E. \& Sirin, M. (2017b). Determination of radioactivity levels and heavy metal concentrations in seawater, sediment and anchovy (Engraulis encrasicolus) from the Black Sea in Rize, Turkey. Marine Pollution Bulletin, 116(1-2), 528-533. DOI: 0.1016/j.marpolbul.2017.01.016

Baltas, H., Sirin, M., Dalgic, G., Bayrak, E.Y. \& Akdeniz, A. (2017a). Assessment of metal concentrations $(\mathrm{Cu}$, $\mathrm{Zn}$, and $\mathrm{Pb}$ ) in seawater, sediment and biota samples in the coastal area of Eastern Black Sea, Turkey. Marine Pollution Bulletin, 122(1-2), 475-482. DOI 10.1016/j.marpolbul.2017.06.059

Banfalvi G. (2011). "Cellular effects of heavy metals". Netherlands, London, NewYork: Springer. DOI: 10.1007/978-94-007-0428-2

Bingöl, D., Ay, Ü., Karayünlü Bozbaș, S. \& Uzgören, N. (2013). Chemometric evaluation of the heavy metals distribution in waters from the Dilovasi region in Kocaeli, Turkey. Marine Pollution Bulletin, 68(1-2), 134-139. DOI: 10.1016/j.marpolbul.2012.12.006

Blettler, M.C.M., Abrial, E., Khan, F.R., Sivri, N. \& Espinola, L.A. (2018). Freshwater plastic pollution: Recognizing research biases and identifying knowledge gaps, Water Research, 143, 416-424. DOI: 10.1016/j.watres.2018.06.015

Calza, C., Anjos, M. J., Castro, C. R. F., Barroso, R. C., Araujo, F. G., \& Lopes, R. T. (2004). Evaluation of heavy metals levels in the Paraiba do Sul River by SRTXRF in muscle, gonads and gills of Geophagus brasiliensis. Radiation Physics and Chemistry, 71(34), 787-788. DOI 10.1016/j.radphyschem.2004.04.092

Canpolat, Ö., Eroğlu, M., Çoban, M.Z. \& Düşükcan, M. (2014). Transfer factors and bioaccumulation of some heavy metals in muscle of a freshwater fish species: A human health concern. Fresenius Environmental Bulletin, 23(2), 418-425.

Canpolat, Ö., Varol, M., Okan, Ö.Ö., Eriş, K.K. \& Çağlar, M. (2020). A comparison of trace element concentrations in surface and deep water of the Keban Dam Lake (Turkey) and associated health risk assessment. Environmental Research, 190, 110012. DOI: $10.1016 /$ j.envres.2020.110012

Cole, J.J. (2003). Interactions between bacteria and algae in aquatic ecosystems, Annual Review of Ecology and Systematics, 13, 291-314 DOI: 10.1146/annurev.es.13.110182.001451

Çelebi, H. \& Gök, G., 2018. Topraklarda otoyol ve trafik kaynaklı ağır metal kirliliğinin değerlendirilmesi. Pamukkale Universitesi Muhendislik Bilimleri Dergisi, 24(6), 1169-1178. DOI: 10.5505/pajes.2016.55632

Çelekli, A., Arslanargun, H., Soysal, Ç., Gültekin, E. \& Bozkurt, H. (2016). Biochemical responses of filamentous algae in different aquatic ecosystems in South East Turkey and associated water quality parameters. Ecotoxicology and Environmental Safety, 133, 403-412. DOI: 10.1016/j.ecoenv.2016.08.002

Çevre ve Şehircilik Bakanlığı, ÇED, İzin ve Denetim Genel Müdürlüğü (ÇŞB). 2017. "Denizlerde Bütünleşik Kirlilik İzleme Programı 2014-2016”. Son erişim tarihi: $\quad 19 \quad$ Mart 2019 http://ced.csb.gov.tr/denizlerde-butunlesik-kirlilikizleme-programi-ozet-raporlari-i-82693 
Dane, H. \& Şişman, T. (2015). Histopathological changes in gill and liver of Capoeta capoeta living in the Karasu River, Erzurum. Environmental Toxicology, 30(8), 904-917. DOI: 10.1002/tox.21965

Dane, H. \& Şişman, T. (2017). A histopathological study on the freshwater fish species chub (Squalius cephalus) in the Karasu River, Turkey. Turkish Journal of Zoology, 41(1), 1-11. https://doi.org/10.3906/zoo1509-21

Dane, H. \& Sisman, T. (2020b). Effects of heavy metal pollution on hepatosomatic index and vital organ histology in Alburnus mossulensis from Karasu River. Turkish Journal of Veterinary and Animal Sciences, 44, 1-11. DOI: 10.3906/vet-1904-50

Dane, H. \& Şişman, T. (2020a). A morpho-histopathological study in the digestive tract of three fish species influenced with heavy metal pollution. Chemosphere, 242, 125212 DOI: 10.1016/j.chemosphere.2019.125212

Demir, A.D. \& Sahin, U. (2017). Effects of different irrigation practices using treated wastewater on tomato yields, quality, water productivity, and soil and fruit mineral contents. Environmental Science and Pollution Research, 24(32), 24856-24879. DOI: 10.1007/s11356-017-0139-3

Demir, E. \& Özdemir, Z. (2013). Investigation of biogeochemical anomalies and interpretation of environmental conditions for $\mathrm{Cu}, \mathrm{Mn}, \mathrm{Zn}, \mathrm{Cd}$ and $\mathrm{Pb}$ in kazanlidotless-Mersin area [Kazanli]- Mersin bölgesinde $\mathrm{Cu}, \mathrm{Mn}, \mathrm{Zn}, \mathrm{Cd}$ ve $\mathrm{Pb}$ için biyojeokimyasal anomalilerin İncelenmesi ve çevresel ortami yorumlanmasi]. Jeoloji Muhendisligi Dergisi, 37(2), 119-140.

Demirak, A., Yilmaz, F., Levent Tuna, A. \& Ozdemir, N. (2006). Heavy metals in water, sediment and tissues of Leuciscus cephalus from a stream in southwestern Turkey. Chemosphere, 63(9),1451-1458. DOI: 10.1016/j.chemosphere.2005.09.033

Dereli Emine, M., Ertürk, A. \& Çakmakçı, M. (2017). Yüzeysel sularda ağır metallerin etkileri ve ötrofikasyon ile ilişkisi. Türkiye Dil Bilimleri Dergisi, 214-230. DOI: 10.18864/TJAS201720

Dökmeci, A. H., Yıldız, T., Sivri, N. \& Öngen, A. (2012). Tekirdağ kıyı sularından toplanan karideslerin ağır metal seviyelerinin belirlenmesi ve insan sağlığına olan toksit etkileri. http://hdl.handle.net/20.500.11776/3197

Duysak, O. (2019). Determination of seasonal metal concentrations in seawater of the Iskenderun Bay in the eastern Mediterranean, Turkey. Fresenius Environmental Bulletin, 28(1), 495-501. https://www.prt-parlar.de/download_feb_2019/

Ellegaard, O. \& Wallin, J.A. (2015). The bibliometric analysis of scholarly production: How great is the impact?, Scientometrics, 105(3), 1809-1831. DOI: 10.1007/s11192-015-1645-Z

Ergül, H.A., Varol, T. \& Ay, Ü. (2013). Investigation of heavy metal pollutants at various depths in the Gulf of Izmit. Marine Pollution Bulletin, 73(1), 389-393. DOI: 10.1016/j.marpolbul.2013.05.018

Genç, T.O. \& Yilmaz, F. (2017). Metal accumulations in water, sediment, crab (Callinectes sapidus) and two fish species (Mugil cephalus and Anguilla anguilla) from the Köyceğiz Lagoon System-Turkey: An index analysis approach. Bulletin of Environmental
Contamination and Toxicology, 99(2), 173-181. DOI: $10.1007 / \mathrm{s} 00128-017-2121-7$

Gokkus, K. \& Berber, S. (2019). Heavy metal pollution in Inebolu and Bartin Ports, Black Sea, Turkey. Indian Journal of Geo-Marine Sciences, 48(10), 16001608.

Herawati, N., Suzuki, S, Hayashi, K., Rivai, I.F. \& Koyoma, H. (2000). Cadmium, copper and zinc levels in rice and soil of Japan, Indonesia and China by soil type. Bulletin of Environmental Contamination and Toxicology, 64, 33-39. DOI: $10.1007 / \mathrm{s} 001289910006$

Kalıpcı, E., Hüseyin, C. \& Toprak, S. (2017). Damsa Baraj Nevşehir Yüzey Suyu Kalitesinin Coğrafi Bilgi Sistemi ile Mekansal Analizi. Karaelmas Fen ve Mühendislik Dergisi, 7(1), 312-319.

Karadavut, I. S., Saydam, A. C., Kalipci, E., Karadavut, S., Ozdemir, C. \& Durduran, S. (2012a). Pollution in Melendiz water basin groundwater. Pol. J. Environ. Stud., 21(3), 659.

Karadavut, S., Delibas, L., Kalipci, E., Ozdemir, C. \& Karadavut, I.S. (2012b). Evaluation of irrigation water quality of Aksaray region by using geographic information system. Carpathian Journal of Earth and Environmental Sciences, 7(2), 171-182.

Karadede-Akin, H. (2009). Seasonal variations of heavy metals in water, sediments, pondweed $(P$. pectinatus $L$ ) and freshwater fish (C. c. umbla) of lake hazar (Elaziğ-Turkey). Fresenius Environmental Bulletin, 18(4), 511-518.

Karayakar, F., Erdem, C. \& Cicik, B. (2007). Seasonal variation in copper, zinc, chromium, lead and cadmium levels in hepatopancreas, gill and muscle tissues of the mussel Brachidontes pharaonis Fischer, collected along the Mersin coast, Turkey. Bulletin of Environmental Contamination and Toxicology, 79(3), 350-355. DOI: 10.1007/s00128007-9246-Z

Kazanci, N., Leroy, S.A.G., Öncel, S., Ileri, Ö., Toprak, Ö., Costa, P., Sayili, S., Turgut, C. \& Kibar, M. (2010). Wind control on the accumulation of heavy metals in sediment of Lake Ulubat, Anatolia, Turkey. Journal of Paleolimnology, 43(1), 89-110. DOI: 10.1007/s10933-009-9316-9

Levac, D.E., Colquhoun, H. \& O'Brien, K. (2010). Scoping Studies: Advancing the Methodology, Implementation Science, 5, 69. DOI: 10.1186/17485908-5-69

Masindi, V. and Muedi, K.L. (2018). Environmental contamination by heavy metals. Heavy metals, 10, 115-132. Doi:10.5772/intechopen.76082

Meriç, E., Avşar, N., Yokeş, M.B., Tuğrul, A.B., Bayari, S., Özyurt, N., Barut, I.F., Balkis, N., Uysal, K. \& Kam, E. (2008). Morphological abnormalities in benthic foraminifers of the Antalya coast. Micropaleontology, 54(3-4), 241-276. http://www.jstor.org/stable/30136845

Minareci, O., Cakir, M. \& Minareci, E. (2018). The study of surface water quality in Buyuk Menderes River (Turkey): Determination of anionic detergent, phosphate, boron and some heavy metal contents. Applied Ecology and Environmental Research, 16(4), 5287-5298. DOI: 10.15666/aeer/1604_52875298 
Pasvanoğlu, S. \& Gültekin, F. (2012). Hydrogeochemical study of the Terme and Karakurt thermal and mineralized waters from Kirşehir Area, central Turkey. Environmental Earth Sciences, 66(1), 169182. DOI: /10.1007/s12665-011-1217-3

Polat, N. \& Akkan, T. (2016). Assessment of heavy metal and detergent pollution in Giresun Coastal Zone, Turkey. Fresenius Environmental Bulletin, 25(8), 2884-2890.

Purwiyanto, A.I.S., Suteja, Y., Ningrum, P.S., Putri, W.A.E., Agustriani, F., Cordova, M.R. \& Koropitan, A.F. (2020). Concentration and adsorption of $\mathrm{Pb}$ and $\mathrm{Cu}$ in microplastics: Case study in aquatic environment. Marine Pollution Bulletin, 158, $111380 . \quad$ DOI: 10.1016/j.marpolbul.2020.111380

Sahin, S., Akpınar, I. \& Sivri, N. (2020). An alternative material for an effective treatment technique proposal in the light of bibliometric profile of global scientific research on antibiotic resistance and Escherichia coli. Environmental Monitoring and Assessment, 192, 714. DOI: 10.1007/s10661-02008678-4

Sponza, D. \& Karaoğlu, N. (2002). Environmental geochemistry and pollution studies of Aliağa metal industry district. Environment International, 27(7), 541-553. DOI: 10.1016/s0160-4120(01)00108-8

Süren, E., Yilmaz, S., Türkoglu, M. \& Kaya, S. (2007). Concentrations of cadmium and lead heavy metals in Dardanelles seawater. Environmental Monitoring and Assessment, 125(1-3), 91-98. DOI: 10.1007/s10661-006-9242-5

Tekin-Özan, S. (2015). Levels of some heavy metals in water and sediment compared with season and some physico-chemical parameters from Antalya Bay. Indian Journal of Geo-Marine Sciences, 44(9), 1393-1400.

Tunca, E., Üçüncü, E., Kurtuluş, B., Ozkan, A.D. \& Atasagun, S. (2013). Accumulation trends of metals and a metalloid in the freshwater crayfish Astacus leptodactylus from Lake Yeniçağa (Turkey). Chemistry and Ecology, 29(8), 754-769. DOI: 10.1080/02757540.2013.810724

Ustun, O.S., Şentürk, İ., Maryam, B., Akbal, F., Bakan, G. \& Büyükgüngör, H. (2018). Temporal variation of mercury in turkish black sea waters and associated risk assessment. Global Nest Journal, 20(2), 345354.

Ustunada, M., Erduğan, H., Yilmaz, S., Akgul, R. \& Aysel, V. (2011). Seasonal concentrations of some heavy metals $(\mathrm{Cd}, \mathrm{Pb}, \mathrm{Zn}$, and $\mathrm{Cu})$ in Ulva rigida J. Agardh (Chlorophyta) from Dardanelles (Canakkale, Turkey). Environmental Monitoring and Assessment, 177(1-4), 337-342. DOI: 10.1007/s10661-010-1637-7

Van Raan, T. (2014). Advances in bibliometric analysis: Research performance assessment and science mapping. Bibliometrics: Use and Abuse in the Review of Research Performance, 87, 17-28.

Vane, C., Turner, G. H., Chenery, S. R., Richardson, M., Cave, M. C., Terrington, R., Gowing C.J.B. \& Moss-Hayes, V. (2020). "Trends in Heavy Metals, Polychlorinated Biphenyls and Toxicity from Sediment Cores of the Inner Thames Estuary,
London, UK”. Environ. Sci.: Processes Impacts, 22, 364-30.

Varol, M. \& Sünbül, M.R. (2018). Multiple approaches to assess human health risks from carcinogenic and non-carcinogenic metals via consumption of five fish species from a large reservoir in Turkey. Science of the Total Environment, 633, 684-694. DOI: 10.1016/j.scitotenv.2018.03.218

Varol, M. (2019). Arsenic and trace metals in a large reservoir: Seasonal and spatial variations, source identification and risk assessment for both residential and recreational users. Chemosphere, 228, 1-8. DOI: 10.1016/j.chemosphere.2019.04.126

Verep, B., Mutlu, C., Apaydin, G. \& Cevik, U. (2012). The trace element analysis in freshwater fish species, water and sediment in Iyidere stream (Rize-Turkey). Pakistan Journal of Biological Sciences, 15(14), 658-665. DOI: 10.3923/pjbs.2012.658.665

Yılmaz, A.B. \& Doğan, M. (2008). Heavy metals in water and in tissues of himri (Carasobarbus luteus) from Orontes (Asi) River, Turkey. Environmental Monitoring and Assessment, 144(1-3), 437-444. DOI: 10.1007/s10661-007-0005-8

Yılmaz, S. \& Sadikoglu, M. (2011). Study of heavy metal pollution in seawater of Kepez harbor of Canakkale (Turkey). Environmental Monitoring and Assessment, 173(1-4), 899-904. DOI: 10.1007/s10661-010-1432-5

Yolcubal, I., Gündüz, Ö.C. \& Sönmez, F. (2016). Assessment of impact of environmental pollution on groundwater and surface water qualities in a heavily industrialized district of Kocaeli (Dilovası), Turkey. Environmental Earth Sciences, 75(2), 170,1-23. DOI: 10.1007/s12665-015-4986-2

Yücel, M. \& Yücel, E. (2013). “On the ecotoxicological effects of heavy metal pollution of industrial origin determination of wheat varieties." Biological Diversity and Conservation, 6(13) 6-11.

Zan, U. B. (2012). Türkiye'de bilim dallarında karşıllaştırmalı bibliyometrik analiz çalışması. Yayınlanmış Doktora Tezi, Ankara Üniversitesi, Ankara. 